\title{
The Conflict of Virtue and Corruption in Shaw's Major Barbara: A Perspective
}

\author{
Yahya Saleh Hasan Dahami \\ Department of English, Faculty of Science and Arts, Al Baha University, \\ Al 65749 Al Mandaq, Saudi Arabia
}

\begin{abstract}
This study focuses on analyzing the conflict between good and evil, and to ascertain the importance of justice and rights in society through a crucial factor that touches all people - poverty and wealth. It aims to detect the measure of the Islamic hints of George Bernard Shaw with particular reference to one of his great plays, Major Barbara, which focused on economy, money, and poverty. The paper begins with a general introduction about some social and dramatic philosophical indications of George Bernard Shaw. After that, it shifts to shed light on (1) the perspective of the dramatist, Bernard Shaw, on the contrastive concept of Good against Evil and (2) the analysis on the central part of the study illustrating the perspectives of the play. Then the paper ends with a summary on the results and discussion of the study to be followed by the conclusion. The study applies the deductive, critical, and analytical approach as a suitable method of literary research.
\end{abstract}

ARTICLE INFO

Article history:

Received: 11 April 2020

Accepted: 6 August 2020

Published: 25 December 2020

DOI: https://doi.org/10.47836/pjssh.28.4.25

E-mail address:

dahami02@gmail.com
Keywords: Belief, clash, drama, George Bernard Shaw, good and evil, morality, salvation, viewpoint, wealth and poverty

\section{INTRODUCTION}

The religionism of George Bernard Shaw has been conventionally treated with a sense of uncertainty, as though he has nothing to do with faith. Bernard Shaw is well acknowledged as a great dramatist, a 
freethinker, a humorist, a social scientist, and an economist. However, critics have neglected, to a great extent, the religious ideas of Shaw's nature. The investigation on his religious thoughts is either poor or just an unavailable thought about his belief in diverse practices. Shaw has spoken his faithful thoughts in the prefaces to his plays as well as in his plays even indirectly. Most likely, the reason for neglecting his spiritual side as believed is because Shaw is a religious man but his ways was covered with an immoral shield.

George Bernard Shaw (1856-1950) is one of the most successful dramatists. He is a "leading literary figure mostly interested in the drama" (Dahami, 2017b, p. 103). As a writer, he came through different works of art, drama and dramatic criticism, journalism, and music under the inspiration of his mother. At the beginning of the twentieth century, Bernard Shaw acquired sufficient knowledge as a dramatist. He produced successful plays such as Passion, Major Barbara, Man and Superman, Heartbreak House, Caesar and Cleopatra, Saint Joan, and many others. Altogether, he wrote critical prefaces about the plays. Many critics say that Shaw is more significant than Shakespeare is. "The point is that Shaw's talent is not merely for conversation but also for dramaturgy" (Bentley, 2010, p. 151). He wrote his first play Passion in 1878 and continued his literary craft with rare pause. This continued until his demise in 1950 till the age of 94, thus ultimately producing more than fifty plays. Bernard Shaw is "a moralist with an insatiable and inextinguishable sense of comedy: a more painfully and utterly inharmonious blend of characteristics" (Gilman, 1907, p. 284).

George Bernard Shaw is a polemic social reformer, a poor yet courteous household of Dublin. His mother rooted in George, her son, affection for music and literature because she was an eminent singer. Shaw became a principal member of the inexperienced Fabian Society, where he authored several pamphlets on a variety of political and social concerns. He started his career through writing novels, but some of the novels were received with limited success. Thereafter, he shifted his disposition towards drama where he found great success.

Bernard Shaw is a writer of polemics, as Einstein appears to have experienced when he related the undertaking of Shavian discussion to Mozart's music. His polemics are thus the more serious,

for polemics are nothing but the art of skilled deception. A prime deice of polemics is the either/or pattern, against which so much has been said in recent times, often by great polemics. Shaw is a great polemicist in his skilled deployment of antitheses. He always forces upon his opponent an alternative which the opponent never wanted to be confronted with and sometimes did not deserve to be confronted with. (Bentley, 1987, p. 146).

His plays changed the attention of audiences from idealistic travails to real problems of society. According to Griffith 
(2002), Shaw "needed also to look again at the institutional focus of his socialism, in particular to reconsider his position with regard to the Fabian Society" (p. 99). The critic, additionally, adds that Shaw "was, in effect, the chief polemicist, star speaker, literary editor, mediator between competing factions, troubleshooter and heart-throb: the virtuoso of every public Fabian performance" (Griffith, 2002, p. 46).

Bernard Shaw produced several dramas that were greatly valued during his first ten years, such as Candida, Mrs. Warren's Profession, and Arms and the Man. He "invented 'Drama of Ideas or The Discussion Play'... in which he discarded the old convention type of plots and incarnated a modern spoof with a serious plot that ushered discussion in the last act of his plays" (Afrozuddin, 2014, p. 9). In 1904, new management for the Court Theater in Chelsea appeared where Bernard Shaw's dramas found a warm reception among people fascinated in a new drama. It is a sort of drama that "was written by dramatists such as Shaw, Arthur Pinero and Henry Arthur Jones, which was influential in London's theatres" (Dahami, 2017a, p. 30). At this time, Shaw had the ability to direct his plays and then he rapidly became prosperous because of their success, concluding with the making of Pygmalion in the main theater of London in 1914. At the end of World War I, he restarted writing plays with a series of five-play on progression called Back to Methuselah and the fabrication of Saint Joan, which guided him in winning the Nobel Peace Prize in
1925. During this date, his dramas have been performed and acted throughout the English-speaking world. He "had the depth and breadth of his eight decades as critic and playwright, spanning the demise of Victorianism and the rise of modernism, to sustain a serious, long-term theatrical venture" (Herren, 2012, p. 199) until his death. Shaw passed away in his home in 1950.

\section{METHODS}

As a literary study, this paper applies the critical, analytical, and descriptive methods as its tools for measuring the events of the study. It is divided into three sections. The first section deals with some crucial standpoints, views, and assessments on the dramatist George Bernard Shaw as a philosopher playwright. The second section covers the main part of the study. Here, the play, Major Barbara, evaluated the concepts of conflict between good and evil as well as poverty and wealth and their consequences in societies. Furthermore, this section focuses mostly on the relationship between the two distant characters, the father and the daughter, Undershaft, and Barbara. The third section summarizes the argument and discussion of the study.

The amalgamation of approaches is essential to understanding. It provides material that would have been apparent for scrutiny of the textual structures in isolation. These are important, particularly in the case of deductive analysis, as there is an inclination to focus on social features of the play, Major Barbara. Therefore, this 
confirms a true methodological analysis putting in mind both visual metaphors and the amalgamation of image within the play. Furthermore, the viewers/critics are not passive; they dynamically will evaluate how the analytical modes unite. In this context, critical-analytical technique can be convenient as it reflects how the analysis will be influenced by both the expected social norms and the public elements.

The study uses the deductive method, which is applied to sufficiently formulate the scheme that accounts for the outcomes obtained via direct observation and reflection to enable logical prediction. Also, there are further effects and impressions to be verified or disproved by theoretical evidence. I feel the importance of comparison between the author and the main character was necessary to correlate the existing sorting method. Analysis and synthesis are employed to recognize the relations between Shaw and Barbara regarding the level relation. The induction supports the review of the prospects for the importance of social issues such as the conflict between good and evil, as well as the significant correlation of wealth and poverty. Qualitative analysis is used to estimate the relationship.

\section{Shaw's Perspective}

George Bernard Shaw justifies reasonably his perspective on Islam, saying that

If any religion had the chance of ruling over England, nay Europe within the next hundred years, it could be Islam. I have always held the religion of Muhammad in high estimation because of its wonderful vitality. It is the only religion, which appears to me to possess that assimilating capacity to the changing phase of existence, which can make itself appeal to every age. I have studied him - the wonderful man, and in my opinion, far from being an antiChrist, he must be called the Saviour of Humanity. (Gandapur, 2009, p. 52).

Such a paragraph proves that Shaw has an excellent admiration, approbation, and respect for Islam and its principles that are faultless, flawless, perfect, ideal, and fit for all humanity everywhere and all over the ages. Shaw has not stopped his thoughts, but he articulated them through his writing and discussable dramas. One of his eminent dramas is Major Barbara, which symbolizes its protagonist as the name of the title. Major Barbara can be recognized as a significant play in the history of modern English drama. Also, it is considered to be one of the most provocative of the works of Bernard Shaw, "a discussion in three long acts" (Crawford, 2005 , p. 88). It is a magnificent play in which it is written at the time when Shaw was fifty years of age. When Shaw wrote the play, he was estimated as a Godless man. It is a means for expressing Shaw's political viewpoint, and it is thought by many critics to be a parody resting on a 'salvation army'.' The play "deals with the corrupting effects of power" (Stafford, 2013, p. 74).

1 An imaginative spiritual camp as opposed to the real concrete word "army" in which this camp is constructed to support and sustain the poor and weak people. 
Bernard Shaw links the play with economics rather than showing religion as a single unit because he believes that the economic situation for a person determines and affects the rest of life, especially the religious principles that are estimated as an organic relationship. Shaw's "religion is above the church, above the cross, above the so-called religious organisations, and also above the traditional religious ethics" (Pathak, 1981, p. 107). However, the religion according to Pathak is Christianity. According to Pathak, religion "cannot have an isolated existence away from the main streams of man's day-to-day economic problems. Religion, according to him, should cover every aspect of man's life. The religion that ignores the economic issue of a man's life is basically anti-man; and it cannot bring about his real progress" (Pathak, 1981, p. 104).

In his vision, Bernard Shaw appreciated the 'Salvation Army' because it ensures and warrants more useful moral assistance than churches. "Shaw's treatment of the Salvation Army in Major Barbara showed that he knew more about religion than some of his churchly critics" (Slosson, 1917, p. 48). The Salvation Army is not an army camp. At the same time, it is not a church neither is it a sheer secular or absolute religious, which means that its name is mixed between secularity and divine. This is proved by a name such as the 'Salvation Army,' which is united from both combinations and shows disparity. The expression 'salvation' refers to redemption, deliverance and rescue, whereas the term 'army' means armed forces, military, and fighting. It can be conceived that Barbara has her own purposive salvation army; similarly, her father Undershaft has his salvation army, but it is for a different purpose. Consequently, "the Salvation Army regards itself as engaged in a continual fight against evil" (Lyall, 1927, p. 31). As it is in Islam, evil should be eradicated by true continuous fight, which is spiritually integrated factually.

\section{The Play's Perspective}

The play, Major Barbara, focuses on the issue that paucity, poverty, and lack are the key factual corruption. This shows that salvation or deliverance is needed to save humanity by the pledge to provide people what they necessarily need to subsist securely. "The Shaw play insists on the corrupting power of institutions" (Nelson, 2014), mainly the one controlled by the father of the hero. The protagonist Major Barbara, "despite lack of money, tries to save the soul of people" (Jain, 2006, p. 109). The weaponries factory mentioned in the play is just a conspiracy scheme to pry the protagonist, Barbara free from inhuman morality, which Bernard Shaw loathed.

One of the main issues the play attempts to tackle is poverty. Major Barbara is a controversial play by George Bernard Shaw. The protagonist, Barbara - a mouthpiece of Shaw - has faith in serving the public via what she calls the Salvation Army; she, in her endeavor, tries to protect them from indulging in prohibited and illegal actions because of poverty. It is advantageous to bring to the mind The Countess Cathleen of 
Yeats, who has similar conduct and virtue with Major Barbara. "Cathleen ... sacrifices her soul to save the poor" (Dahami, 2016, p. 1192). The case is comparable with the Countess Rosmarin of Christopher Fry, who accepts to "leave her house; the Countess portrays the concept of sacrifice to redeem and deliver others. She disbelieves in vehemence and confrontation as a means of reaching human delivery" (Dahami, 2018, p. 27).

Barbara trusts herself that she can help poor people and remains true to her belief only by receiving donations from benefactors who earn their income in the right way, which denotes an Islamic direction. The play, Major Barbara, is a drama about an officer working in the Salvation Army. The main character, Major Barbara Undershaft, is disappointed by social harms, evils, and misfortunes. Her values prevent her to receive money from armament producer who chances to be her father Undershaft. "Through this play, Shaw has tried to focus attention on a great social evil. Not only is poverty the greatest of social evils, but it is also the root cause of all other evils and crimes" (Reddy, 2010, p. 107). Bloom (2005), adds, "It is a crime to endure it, a crime to be content with it, and it is the mother of all crimes of brutality, corruption, and fear" (p. 169). Barbara sheds light on the point saying: "There is no wicked side: life is all one. And I never wanted to shirk my share in whatever evil must be endured, whether it be sin or suffering. I wish I could cure you of middleclass ideas, Dolly" (Shaw, 2002, p. 80).

For Shaw as stated by Undershaft, poverty is a crime. It is confirmed through the discussion between Undershaft and Cusins. Undershaft insists upon his position by saying:

Cusins: Do you call poverty a crime?

Undershaft: The worst of crimes. All the other crimes are virtues beside it: all the other dishonors are chivalry itself by comparison. Poverty blights whole cities; spreads horrible pestilences; strikes dead the very souls of all who come within sight, sound, or smell of it. What you call crime is nothing: a murder here and a theft there, a blow now and a curse then: what do they matter? They are only the accidents and illnesses of life. (Shaw,1992, p. 137).

Moreover, Shaw shares his view about the poor people saying, "they do not want a revolution, they want a job... a job or even a meal will stop them at any time" (Murdoch, 2014, p. 78) from indulging in any unlawful activity. Poverty "is the worst crime" (Patterson, 2002, p. 109), which is one of the most imperative thoughts of Bernard Shaw in Major Barbara that negotiates a very dangerous topic, which Islam pays great concern to. One of its cures is simply in paying zakât-charity from rich people to those starving. However, what is zakat? Allah Almighty says:

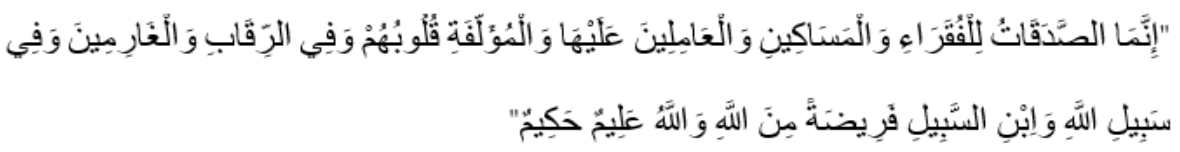


- As-Sadaqat (here it means Zakât) are only for the Fuqara' (poor) and Al-Masakin (the poor) and those employed to collect (the funds), and to attract the hearts of those who have been inclined (towards Islam), and to free the captives, and for those in debt, and for Allah's Cause, and for the wayfarer (a traveller who is cut off from everything); a duty imposed by Allah. And Allah is AllKnower, All-Wise" (Quran, 9:60, from AlHilali \& Khan, 1997, p. 254).

In Islam, it is a duty imposed by Allah, The All-Knower, that poverty should be lessened in the society via taking a very little specific portion from the rich to be given to the poor. Such a case is processed on the condition that the rich people must deal and gain their wealth and money by legal and lawful ways - against Andrew Undershaft, Barbara's father, and all those who behave like him. "The people of misguidance and its leaders are rambling along with the guidance of the devil in his perversion; they portray the right image as falsehood and the falsehood as right. They try to philosophize falsehood and strenuously try to demonstrate ... falsehood to delude those who do not have sufficient knowledge that their saying is indisputable true" (Al Ashqar, 1997, p. 321). Furthermore, the argument is supported by Undershaft declaring:

The more destructive war becomes the more fascinating we find it. No, $\mathrm{Mr}$ Lomax, I am obliged to you for making the usual excuse for my trade; but I am not ashamed of it. I am not one of those men who keep their morals and their business in watertight compartments.
All the spare money my trade rivals spend on hospitals, cathedrals and other receptacles for conscience money, I devote to experiments and researches in improved methods of destroying life and property. I have always done so; and I always shall (Shaw, 2002, p. 16).

This condition is the same belief that Barbara struggles to achieve but in an antithesis to her father. Poverty is a very ineffective and devastating habit in society. For that reason, Prophet Mohammad (Prayers and Peace be upon him) regularly used to seek refuge from it, saying, "O Allah! I seek refuge in You from disbelief and poverty" (Hamid, 2003, p. 83). Such supplication from the Prophet PBUH indicates its significance. Thus, the poor should be given from the zakat. However, the rich people,

who refuse to pay the Zakât-Charity are not only liable to chastisement in the Hereafter; they also place their worldly wealth and assets at great risk of loss; for they have willfully deprived the poor and the eligible of the right they hold in their wealth (The Zakât handbook, 2007, p. 7).

Opposite to Doctor Faustus, who mentioned the seven deadly sins, Undershaft mentions other deadly seven elements. However, these elements are to increase his views towards such worldly means. He comments: "Yes, the deadly seven... Food, clothing, firing, rent, taxes, respectability, and children. Nothing can lift those seven 
millstones from Man's neck, but money; and the spirit cannot soar until the millstones are lifted" (Shaw, 2002, p. 72). This demonstrated his deviated direction towards evil and the devil. Undershaft neglects his moral responsibility leaving his house and wife to make his massive prosperity by selling mortars. "That's Andrew all over. He never does a proper thing without giving an improper reason for it" (Shaw, 2002, p. 53). Besides, "Undershaft jabs away at religion, government, and morality" (Suskin, 2003, p. 22).

He does not care whether his money comes from lawful conduct or not. Undershaft's business is "the tearing apart of men's bodies which is the effect of the munitions that Undershaft supplies to the world's battlefields" (Herren, 2012, p. 197). He confirms,

I am not one of those men who keep their morals and their business in watertight compartments. All the spare money my trade rivals spend on hospitals, cathedrals, and other receptacles for conscience money, I devote to experiments and researches in improved methods of destroying life and property. I have always done so; and I always shall. (Shaw, 2002, p. 16).

This proves that he does not care about anything except personal benefits. He adds,

your Christmas card moralities of peace on earth and goodwill among men are of no use to me. Your Christianity, which enjoins you to resist not evil, and to turn the other cheek, would make me a bankrupt. My morality - my religion - must have a place for cannons and torpedoes in it. (Shaw, 2002, p. 16).

Shaw draws on Barbara, as his mouthpiece, to present his faith. She makes it clear, illuminating how the relationship between God and his creatures should be. Barbara orates:

you know, and I know that God is with us always and everywhere. We do not need a cathedral to worship Him in. Here in this old shed no less than beneath God's open sky, we can draw nearer to Him. Some of you feel Him near you even now, and feel, too, how much you need Him. Won't you let Him come into your life now, today, as so many have done before? You want His strength, His guidance, His comfort: you need His forgiveness and friendship. Some of you turn away from Him in bitterness at the hardship of your lives, saying that you do not want God: you want happiness and beauty. God will give you both. There is no beauty like the beauty of the newly saved who has found the unspeakable happiness that only the consciousness of God's presence and love can give (Shaw, 1951, p. 39).

The previous passage significantly demonstrates Shaw's philosophy and perspective, which, to a reasonable extent, is identical with a principle in Islam. In Islam, Muslims believe that God is with us always 
and everywhere. All true believers feel Him near them every time and everywhere. They feel that people need His blessing and support. All humanity, consciously or unconsciously, wants His strength, His guidance, and His satisfaction as well as His forgiveness, compassion, and clemency. There is no real happiness or beauty for those who go astray from God.

Barbara superficially realizes her belief that the closing influence in the presentation may be an inspiration for the spectators in the face of the protagonist's eventual honesty. An understanding of Shaw's contradictory viewpoint on the way to the explanations of well and evil in consort with an understanding of his profound and hopeful belief in the control of life and its force, need to make critics, readers, and audiences cautious of whichever account climaxes in misery. Shaw is moving in the direction of a combination of the observations in his theoretical description of the life and its force that, to his belief, "nothing is more sacred than human life" (Dey, 1985, p. 154), which confirms his religiosity but not Christianity.

Behind the traditional marital theme, the critics, readers, and audiences' glance at the more profound implication. Andrew Undershaft has a "watchful, deliberate, waiting, listening face, and formidable reserves of power" (Shaw, 1951, p. 57). He steadily discloses his power as he counters all his wife's moves through his cunning meekness, presenting a disposition of rebellion contrary to her control by which some members are motivated. Charles
Lomax runs to bring his musical part to cheer the uncomfortable assembly. Cusins orates on the significance of Greek scholarship, whereas Barbara is invigorated to elucidate the attraction of her task to help those starving.

Barbara pays attention to her father with increasing interest and pleasure, like her newly appeared father. He has swiftly presented his concern of her profession to which Barbara devoted her life. Salvation, as an ingenious subject, is thrown back and forth in a traditional performance. The pedestrian style enlarges and hastens into the first proposition of image and representation. Undershaft mockingly states: "I am rather interested in the Salvation Army. Its motto might be my own: Blood and Fire" (Shaw, 2002, p. 15) in which Undershaft understands the meaning negatively or according to his devilish spirit to mean that the army is fighting an armed camp and salvation refers to death.

Undershaft declares his mischievous spirit and intent stating that

The Government of your country! I am the Government of your country, I and Lazarus. Do you suppose that you and half a dozen amateurs like you, sitting in a row in that foolish gabble-shop, govern Undershaft and Lazarus? No, my friend, you will do what pays us. You will make war when it suits us and keep peace when it doesn't ... When I want anything to keep my dividends up, you will discover that my want is a national need. When other people 
want something to keep my dividends down, you will call out the police and military. And in return you shall have the support of my newspapers and the delight of imagining that you are a great statesman-Undershaft, the armament maker, in Shaw's Major Barbara (Neumann, 1938, p. 194; Shaw, 2002, p. 59).

Furthermore, McCormick (1965), shares ideas about the nature of Undershaft and his devilish craft presenting that Undershaft is only a representation of the waste immoral society which is better described by T. S. Eliot in his sophisticated poem The Waste Land

It has been denied that either Vickers, or Zaharoff, had much influence with British governments, or government departments and Mr. J. D. Scott writes that in 'dealing with the legend of basil Zaharoff ... Britain was quite outside his sphere of influence. It is over the foreign dealing that the legend of Undershaft-Zaharoff hangs thickest. It would be naïve to imagine that the standards of business ethics in the Balkans and in South America in the seventies and eighties were the standards of Whitehall, or the Bank of England. Bribery was not accidental, or occasional, but essential and systematic in every field of commerce. It would be equally naïve, however, to imagine that when Zaharoff paid bribes, the money paid appeared under a ledger of entry of 'Bribes' in the books in London. The evidence, what there is of it, is quite of another kind, of inferences from notes of expenses, of guarded phrases in private letters' (McCormick, 1965, p. 116).

The Father, Undershaft, comments: "My religion? Well, my dear, I am a Millionaire. That is my religion" (Shaw, 2002, p. 30), which discloses his secular desire and belief is money. His heart is busy with wealth and riches but no place for mercy, compassion, or clemency for the poor or those in need. Opposite to Shaw's belief, Undershaft's religion is money, which denotes that his target is to obtain money by any means, legally or illegally, validly or criminally and this is against the rules and principles of Islam, which orders Muslims to behave according to the preaching and instruction of Islam. Trade and commerce should deal with lawful actions, words, or deeds. The Prophet Mohammad says: "Do not cause harm or return harm "لا ضرر ولا إضرار" (Ibn Hanbal, 2008, p. 693).

Consequently, such affirmations and statements set Undershaft evidently in disagreement and incongruity with his daughter and this associated him with her in an outlandish company. However, for a dissimilar motive, Andrew Undershaft permits all men his explanation of decency. Furthermore, Hadfield has commented that Undershaft is a Mephistophelean bearer of excruciating communal realities. Besides, "Undershaft's maxims and belligerent deductions do more than amuse the audience" (King, 2012, p. 165). This is because amusing is a sort of positivity, 
but his action is negative, deleterious, and undesirable.

According to Barbara, when the discussion transforms from money to humankind, she counters her father declaring, "There are no scoundrels" (Shaw, 2002, p. 17). Barbara's words are slang and prosaic, but the quality is forceful, and she runs into rhythm and regularity as she develops her elucidation of good and evil. Shaw, 'though skeptical both of Hugo's emotional excess and of Christian theology and religious organizations in general, presents the Christian concepts of sin and salvation as inseparable from the concrete human world of politics and money" (Christian, 2015, p. 1). Here, Barbara stands against her father's immorality, depravity, and corruption: "There are neither good men nor scoundrels: there are just children of one Father; and the sooner they stop calling one another names the better. You needn't talk to me: I know them" (Shaw, 2002, p. 17).

Together, Barbara and her father realize the wager, and everyone hopes to attract the other to her/his side. In such a point, it is observed that the martial account of the combat locations indicates that Barbara innocently warns her rival father that his acceptance of the challenge may end in his relinquishing mortars for the benefit of the salvation of souls. However, on the contrary, he confirms that she might give up the Salvation Army for the benefit of mortars and weapons, believing in fighting and aggression. They end with shaking hands. It is a mistaken notion in the belief of the father, Undershaft, "that a munitions factory might be the gateway to social reform" (Hadfield \& Reynolds, 2013, p. 52).

Concerning the particular aspect of the plot, an enormous percentage of the action of the play is consumed in the first Act. Centrally via this Act, it might be obvious that the fight for settlement money is gained since Andrew Undershaft starts his reintegration with the family by a tricking question: "Now what can I do for you all?" (Shaw, 2002, p. 14). Here, the question shows intricateness. The mother, Lady Britomart, who explains the past squabbles with Andrew Undershaft on the topic, suggests such action since the conventional arrangement. Hence, both the 'birth-mystery' and the Undershaft legacy subject require the attendance of a foundling.

Barbara challenges beast violence and fetches it into a condition of humiliation and trepidation to the degree of tears. At this degree of ostensible triumph, Undershaft enters to watch her system of alteration of Bill's brutality to Jenny Hill. Barbara paradoxically requests her father to combat for his redemption. The control is almost full as Undershaft is called "to brave manhood on earth and eternal glory in heaven" (Shaw, 2002 , p. 32) when the crisis moment is devastated by the drum's Dionysiac hitting. The power of Barbara is smashed before herself and the audiences without realizing that fact or its reason. Cusins, the rhythmist, sticks down the incident.

For Undershaft, control and the inclination to abolish anything that threatens authority is the root of wealth, power, 
and better life. All other merits are just superfluities fabricated upon this root. Andrew Undershaft has perceived the forte of Barbara's principles. He scrutinizes those of Cusins, who says, "The business of the Salvation Army is to save, not to wrangle about the name of the pathfinder Dionysus or another: what does it matter" (Shaw, 2002, p. 36).

In the second act, Andrew Undershaft has assumed gallant merits. However, he is undoubtedly connected with what might traditionally be explained as malevolent for the reason that he is a foundling who did not get estimation and respect from his family or the society as a legitimate born. When Major Barbara came back from the stimulating meeting, it demonstrates that she relies on money, and Andrew Undershaft creatively formulates the way for his disloyalty to her by praising her magnanimity. Barbara's recognition with Islam is defined at the level where Barbara rejects and refuses the money offered by her father, the war inflamer, and the killer.

At this instant of self-assured affirmation, the soldiers are approaching the garden of the Salvation Army, and Mrs. Baines brings delightful news for Major Barbara. Lord Saxmundham, the owner of Bodger's whiskey and the devastation of slums, is going to bid the Salvation Army a grant of five thousand pounds. Mrs. Baines admits that another similar sum will be offered by Andrew Undershaft who raises the pen to write the cheque, encircled by an appreciative troop. Barbara, simultaneously, moves the far side of the place and shockingly stands to observe as a reaction to her refusal of the process. She tries to struggle against the money that, in her belief, is murky and has come from a prohibited means and protests. She loudly declares her refusal of the granted polluted money, saying: "Stop." (Undershaft stops writing: they all turn to her in surprise.) Mrs. Baines: are you really going to take this money? (Shaw, 2002, p. 45)

The start of the second act serves as both a plot link and an interval of prosaic soundness following the forceful emotionalism of the previous happening. It decelerates the moving in tone. The action proposes little of the figurative nature and intensification of Undershaft's authorities as a leader of darkness. Before the end of the act, a discussion between the three main characters divulges the track towards the closing action of the play. When the family is arranging to go to see the factory of armaments, Barbara commented: "I have always thought of it as a sort of pit where lost creatures with blackened faces stirred up smoky fires and were driven and tormented by my father" (Shaw, 2002, p. 61).

Skillfully, indeed, the actors acted out their given parts in a play of comic antitheses that, ideologically, balanced around the armaments maker's Andrew Undershaft and the Salvation Army mademoiselle, his daughter Barbara Undershaft, a believer of God. The actors "touched off the polemic fire in Shaw's lines. Yet in the performance they retained many imaginative aspects of the unique, the individual, in their characterization of England's elite and 
cockney social types of the late Victorian era" (Miller, 2010, p. 343).

In a deep situation of despair, downfall and sadness, Barbara recollects the seed of revival and recovery confirming, "There must be some truth or other behind all this frightful irony" (Shaw, 2002, p. 62). It is this voracious energy of life, the cause of her spirituality, which leads others to love Barbara, making Cusins ascribe to her the exuberant soul of Dionysus. At the same time, the father, Andrew Undershaft, distinguishes her authority to renovate humanity. Lady Britomart spontaneously articulates an answer to the ethical predicament.

In this play, Barbara struggles not to lose her veracity for the sake of worldly authority and prosperity even to face one of her dear members of the family, her father. She also intentionally abandons her fiancée, Cusins, to face the interrogation alone. This is precisely because he abandoned her at a time of purification. Andrew Undershaft makes the duties unblemished. The proprietor of the foundry should have the honesty of nobility using the authority in his hands somewhat, knowing that its significance as a tool of welfare upon the mystical pyramid may be constructed. He says, "I had rather be a thief than a pauper. I had rather be a murderer than a slave" (Shaw, 2002, p. 74). "Poverty is almost disbelief" (Al-Qarni, 1999/2005, p. 215). Paucity and captivity might be eradicated by such influence, but it should be wisely used. For the most significant use of authority and for its ingenious use, the dreamer must become a monarch.
The good and evil methods of God and the devil are perceived to be aspects of divine authority, which can be interpreted by the contrast negotiation between the hand of well, Barbara, and the gape of evil symbolized by her father, Andrew Undershaft. The negotiation starts as an insightful divergence on the nature of morality but concludes in an integrated revelation. Cusins responds to Barbara about her spiritual influence, saying: "You cannot have power for good without having power for evil too" (Shaw, 2002, p. 79).

Major Barbara, on the one hand, declares an idea in this play that, "in one of those passages of singular eloquence in which Mr. Shaw betrays the poet of whom he is lurkingly ashamed: My father shall never throw it in my teeth again that my converts were bribed with bread" (Harvey, 1907 , p. 287). On the other hand, "the scenes between Barbara and every other character unfold a constant thickening, doubling, and complicating of any simple sense of virtue, vice, right, wrong, salvation or damnation" (Herren, 2012, p. 197). The influence used for material happiness, as Barbara understands, will make humanity do away with physical loads to liberate their emotional state for greater struggle. The combat that Major Barbara has persisted against complacent pride, until the end, shows that she "does not mince her words" (Ollevier, 2012, p. 47).

\section{RESULTS AND DISCUSSION}

This part represents a sort of argument on the play and playwright as two integrated 
or inseparable sides. Several of Shaw's plays are acknowledged for their involved arguments, and Major Barbara is no exception. George Bernard Shaw himself called the play "a discussion in three long acts," but it is of great controversial influences, quarrels, and estimations. Much of the action in the play consists, actually, of words. The action or the conflict is seen mostly through the mouth instead of a blade or gun. As soon as the play was issued in 1907, Shaw added a lengthy preface with several of his plays, providing further argument about the play Major Barbara.

The drama Major Barbara copes with the contradictory and paradoxical state. The efforts of the Salvation Army are to dry and rub down social evil problems. Unfortunately, Major Barbara realizes that desiccating and wiping out social evils can only be done via the charity of those whose financial and monetary support is responsible for making such evils and harms. This social drama concentrates principally on the theme of money, and on the societal behavior of the individual in the society, along with the denunciation and condemnation of poverty. Therefore, this reveals the materialistic cynicism and pessimism of George Bernard Shaw who takes into consideration poverty as the foundation of all vices, immoralities, and evils.

Furthermore, the play is distinguished for its eccentric attitudes toward principles in addition to its irony, sarcasm, and satire as well as comicality. Irrespective of the serious disposition of the issues observed in this drama - trade, and religion, wealth and shortage, cynicism and idealism - it is uncomplicated to oversee the fact that the play is actually filled with humor and farce. George Bernard Shaw uses Major Barbara to entertain his spectators, making them laugh while considering questions that are as significant nowadays as when it was first produced.

\section{CONCLUSION}

The substance of Major Barbara, nevertheless, is obviously and earnestly concerned with a theoretical religious question staged in near tragic-comic terms, regarding the aspects of human morality. There is a probability of some stable figurative association between the incongruent elements of good and evil. Through Major Barbara, George Bernard Shaw shows an end not of depression but of prolific conciliation, the nature of which shall go on with showing the conflict between good and evil. Good and evil are presented through two members of the same family.

The character Major Barbara represents goodness with all its virtue and various positive meanings. Her father is an example of evil in one of the most prominent faces of life using money and its treatments as methods of gaining and, at the same time, showing the importance it expends. Shaw utilized Barbara to be his mouthpiece in fighting evil even to face the dearest parent, her father. It is a principle and belief. 
George Bernard Shaw is not a Muslim, but through his play, Major Barbara, it is found, to a great extent, that the play deals with some tangible Islamic examples or perspectives. One of the most crucial issues Shaw tries to work out is the conflict between good and evil, and the importance of justice and rights in the society through a crucial factor which touches all people e.g., the economy and money. He, through Major Barbara, alleviates a moral perspective that is identical to the Islamic one.

\section{ACKNOWLEDGEMENT}

It is my pleasure to show gratitude to the Saudi Digital Library (SDL) for the service provided to academics and scholars. It provided me with generous support and sustenance availing from the rich sources with no trouble, which was of great assistance to achieve my task.

\section{REFERENCES}

Afrozuddin, M. (2014). The face behind the mask: Selected plays of George Bernard Shaw (Doctoral thesis), Jawaharlal Nehru Technological University, India.

Al Ashqar, O. (1997). Purposive Islamic lectures. Amman, Jordan: Dar Annfa'es for Publishing and Distribution.

Al-Hilali, M. T., \& Khan, M. M. (1997). The Noble Qur'an: English translation of the meanings and commentary. Madinah, Saudi Arabia: King Fahd Complex for the Printing of the Holy Qur'an.

Al-Qarni, A. A. (2005). Don't be sad (F. Shafeeq, Trans.). Riyadh, Saudi Arabia: International Islamic Publishing House. (Original work published 1999).
Bentley, E. (1987). The playwright as a thinker: A study of drama in modern times. Minneapolis, USA and London, England: University of Minnesota Press.

Bentley, E. (2010). Playwright as thinker: A study of drama in modern times. Minneapolis, USA: University of Minnesota Press. Retrieved September 4, 2016, from https://www.proquest. com. doi: $10.5749 / \mathrm{j} . c t t t v 11 \mathrm{j}$

Bloom, H. (2005). Dramatists and dramas. Philadelphia, USA: Chelsea House Publishers.

Christian, M. (2015). Bought with silver: Victor Hugo, George Bernard Shaw, and the economics of salvation. Religion \& Literature, 47(2), 1-22.

Crawford, M. K. (2005). The annual of Bernard Shaw studies (Vol. 25). Pennsylvania, USA: The Pennsylvania State University Press.

Dahami, Y. S. H. (2016). Yeats: Resurgence of poetic drama in the twentieth century. Journal of Taibah University for Arts and Humanities, 9, 11791217. doi: 10.36346/sarjall.2020.v02i01.001

Dahami, Y. S. H. (2017a). Revival of poetic drama: T. S. Eliot's contribution to the genre. Riga, Latvia: Noor Publishing.

Dahami, Y. S. H. (2017b). Introduction to English literature. Riga, Latvia: Noor Publishing.

Dahami, Y. S. H. (2018). Sanguinity in Fry's the Dark is Light Enough. Umm Al-Qura University: Journal of Languages and Literature, 21, 10-43.

Dey, M. (1985). A study of the political ideas in the dramatic works of George Bernard Shaw (Doctoral thesis), Gauhati University, Gauhati, India.

Gandapur, F. U. K. (2009). God created the universe with the purpose to serve humankind. Peshawar, Pakistan: Khyber Mail Printers \& Publishers.

Gilman, L. (1907). Mr. Shaw's new volume of plays. The North American Review, 186(623), 284-288.

Griffith, G. (2002). Socialism and superior brains: The political thought of George Bernard 
Shaw. London, England: Routledge. doi: $10.4324 / 9780203210833\}$,

Hadfield, D. A. \& Reynolds, J. (2013). Florida Bernard Shaw: Shaw and feminisms: On stage and off. Gainesville, USA: University Press of Florida.

Hamid, A. A. (2003). Moral teachings of Islam: Prophetic traditions from al-Adab al-Mufrad by Imam Al-Bukhari. Oxford, England: Roman Altamira Press.

Harvey, G. (1907). The North American Review (Vol. 186). New York, USA: The North American Review Publishing Co.

Herren, G. (2012). The comparative drama conference Series 9: Text \& presentation. Jefferson, USA: McFarland. Retrieved September 4, 2016, from https://www.proquest.com

Ibn Hanbal, A. (2008). Musnad al-Imām Ahmad ibn Hanbal [The Predicate of al-Imām Ahmad ibn Hanbal] (Vol. 2, Hadith No. 2912). Jeddah, Cairo, Egypt: Dar Al-Manhaj wa-Jamaiat AlMaknaz Al-Islami.

Jain, S. (2006). Women in the plays of George Bernard Shaw. New Delhi, India: Discovery Publishing House.

King, R. L. (2012). The ethos of drama: Rhetorical theory and dramatic worth. Washington, USA: Catholic University of America Press. Retrieved September 4, 2016, from https://www.proquest. com. doi: $10.2307 /$ j.ctt2852cx

Lyall, A. (1927). A critical examination of the salvation army from the standpoint of purpose and methods (Master's thesis), University of Southern California, USA. UMI Number: EP67907.

McCormick, D. (1965). Peddler of death: The life and times of Sir Basil Zaharoff. New York, USA: Holt, Rinehart and Winston.

Miller, C. E. (2010). The Critics'Review. USA: Xlibris Corporation.
Murdoch, N. H. (2014). Origins of the Salvation Army. Eugene, USA: WIPF and Stock Publishers.

Nelson, B. (2014). Major Barbara/the Light in the Piazza/Guys and Dolls. Theatre Journal, 66(4), 604-608. Retrieved October 10, 2018, from https://www.proquest.com

Neumann, R. (1938). Zaharoff: The armaments King. London, England: G. Allen \& Unwin, Limited.

Ollevier, S. (2012). Ambivalence towards the new woman in the plays of George Bernard Shaw (Master's thesis), Ghent University, Belgium.

Pathak, D. (1981). The religious ideas of George Bernard Shaw (Doctoral thesis), Gauhati University, Gauhati, India.

Patterson, J. (2002). Scribbled stories. San Jose, USA: Writers Club Press.

Reddy, P. S. (2010). Bernard Shaw-social reformer (Doctoral thesis), Sri Venkateswara University, India.

Shaw, G. B. (2002). Major Barbara. Mineola, Canada: Dover Publications, Inc.

Shaw, G. B. (1992). Pygmalion and Major Barbara (M. Holroyd, Ed.). New York, USA: Bantam Classic.

Shaw, G. B. (1951). Major Barbara: A screen version. Baltimore and Maryland, England: Penguin Books.

Slosson, E. E. (1917). Six major prophets. Boston, USA: Little, Brown, and Company.

Stafford, T. J. (2013). Florida Bernard Shaw: Shaw's settings: Gardens and libraries, Gainesville: University Press of Florida. Retrieved September 3, 2016, from https://www.proquest.com

Suskin, S. (2003). Broadway yearbook 2001-2002: $A$ relevant and irreverent record. Cary, USA: Oxford University Press. Retrieved September 3, 2016, from https://www.proquest.com

The Zakât handbook: A practical guide for Muslims in the West. (2007). California, USA: The Zakat Foundation of America. 